\title{
PENDEKATAN INTEGRASI-INTERKONEKSI DALAM KAJIAN MANAJEMEN DAN KEBIJAKAN PENDIDIKAN ISLAM
}

\section{Imam Machali}

Dosen Fakultas Ilmu Tarbiyah dan Keguruan

UIN Sunan Kalijaga Yogyakarta

Email: imam.machali@uin-suka.ac.id

DOI: http://dx.doi.org/10.20885/tarbawi.vol8.iss1.art3

\begin{abstract}
This article discusses the integrative-interconnective approach towards the study of management and policy of Islamic education with a focus on the practice of learning management in 2013 Curriculum. It is known that the policy of 2013 Curriculum develops three areas in an integrative-interconnective way in the form of attitude, knowledge and skills. These three areas are one integral unit and becomes a requirement in the learning process that is relevant with the integrative-interconnective approach. In 2013 Curriculum, the integrativeinterconnective approach is implemented not only at the level of cognition, but also at the level of practice-application of the learning process. The learning management in 2013 Curriculum is an example of a good practice of the integrative-interconnective approach in which three areas are integrated, namely attitude, knowledge and skills as reflected in Core Competence-1 (spiritual attitude), Core Competence-2 (social attitude), Core Competence-3 (knowledge) and Core Competence-4 (skills). These four Core Competences are one integral requirement that must be fulfilled, achieved and implemented in the learning and teaching process.
\end{abstract}

Keywords: integrative-interconnective approach, policy, 2013 Curriculum

\section{Abstrak}

Artikel ini membahas praktik pendekatan integrasi-interkoneksi dalam kajian manajemen dan kebijakan pendidikan Islam yang difokuskan pada praktik manajemen pembelajaran pada kebijakan kurikulum 2013. Diketahui bahwa kebijakan kurikulum 2013 mengembangkan tiga ranah secara terintegrasi-interkoneksi berupa sikap (attitude), pengetahuan 
(knowledge), dan keterampilan (skill). Ketiga ranah tersebut adalah satu kesatuan utuh dan menjadi tagihan dalam proses pembelajaran yang relevan dengan konsep integrasi-interkoneksi. Dalam Kurikulum 2013, implementasi pendekatan integrasi-interkoneksi dilakukan tidak hanya pada ranah pemikiran saja, akan tetapi pada praktik-aplikatifnya dalam proses pembelajaran. Manajemen pembelajaran dalam kebijakan kurikulum 2013 adalah contoh praktik integrasi-interkoneksi yang baik, dimana Kurikulum 2013 mengintegrasikan tiga ranah kompetensi yaitu sikap (attitude), pengetahuan (knowledge), dan ketrampilan (skill) yang diimplementasikan dalam KI-1 (sikap spiritual), KI-2 (sikap sosial), KI-3 (pengetahuan), dan KI-4 (keterampilan). Keempat aspek ini (kompetensi Inti) merupakan satu kesatuan (integrasi) tagihan yang harus terpenuhi, tercapai dan terimplementasikan dalam proses belajar mengajar.

Kata Kunci: Integrasi-Interkoneksi, kebijakan, Kurikulum 2013

\section{Pendahuluan}

"Integrasi-interkoneksi" memang kata yang mudah diucapkan, akan tetapi "sulit" diimplementasikan. Sebab men-syariat-kan pemahaman, wawasan, penguasaan tidak hanya satu disiplin ilmu yang menjadi fokus keahliannya saja, akan tetapi juga persinggungan (intersection) dengan ilmu-ilmu lain, bahkan inter dan multidispliner. Tidak hanya itu, kemampuan mendialogkan, menghubungkan, dan praktik-aplikatif ilmu juga sangat diperlukan untuk menjadikan konsep integrasi-interkoneksi benar-benar membumi dan applicable.

Konsep dan praktik integrasi-interkoneksi sangat dibutuhkan untuk mempersempit ruang dualisme atau dikotomi ilmu yang memisahkan antara pendidikan umum dari pendidikan agama yang kemudian berdampak pada pemisahan dan pemilahan kesadaran keagamaan dan ilmu pengetauan umum. Hal ini pada tataran operasionalnya nampak pada pemisahan antara madrasah dan sekolah, mata pelajaran umum dan mata pelajaran agama, Fakultas Agama dan Fakultas Umum, dan lain-lain. Pandangan dikotimistis ini menurut Fazlur Rahman (1984: 33) menjadi penyebab kemunduran penguasaan ilmu pengetahuan di dunia Islam, meskipun problem dikotomik sesungguhnya bukanlah hal yang baru. Persoalan dikotomi dalam pendidikan Islam menurut Kartanegara (2005: 19) semakin menampakkan problematikanya ketika sistem pendidikan sekuler Barat diperkenalkan ke dunia Islam melalui imperialisme. 
Sejarah dikotomi ilmu dimulai sejak zaman pertengahan yaitu pada masa dinasti Ummayah. Pada saat itu, ilmu pengetahuan dan teknologi sudah mulai berkembang dikalangan umat Islam. Tradisi ini mengalami kemajuannya pada masa Abbasiyah, penerjemahan naskah-naskah kuno, penemuan ilmu-ilmu hitung dan fisika hingga pendirian Baitul Hikmah yang menjadi puncak peradaban dan kejayaan Islam. Masa Abbasiyah ini dikenal sebagai masa puncak kejayaan Islam (Hitti, 1974: 25).

Upaya integrasi ilmu pengetahuan dalam Islam terus dilakukan oleh para ilmuwan muslim seperti Fazlur Rahman, Seyyed Hossein Nasr, Ziauddin Sardar, Ismail Raji al-Faruqi, dan Syekh Muhammad Naquib al-Attas. Di Indonesia upaya integrasi ilmu juga terus dikembangkan oleh para ilmuwan dan akademisi sebagai contoh adalah Kuntowijoyo dengan konsep "Pengilmuan Islam". Al Qur'an sebagai paradigma yang dilakukan dengan dua cara pertama integralisasi yaitu pengintegrasian kekayaan keilmuan manusia dengan wahyu, dan kedua objektifikasi yaitu menjadikan pengilmuan Islam sebagai rahmat untuk semua orang (Kuntowijoyo, 2004: 49). Imam Suprayogo dengan konsep pohon ilmu yang mengilustrasikan integrasi ilmu-ilmu bagaikan sebatang pohon yang utuh, agama menjadi dasar pengembangan sains, dan sains dipandang merupakan bagian dari kajian keagamaan Islam.

Integrasi adalah upaya memadukan ilmu umum dan ilmu agama (Islam). Integrasi ini dalam pandangan Amin Abdullah akan mengalami kesulitan dalam memadukan studi Islam dan umum yang kadang tidak saling akur karena keduanya ingin saling mengalahkan, oleh karena itu diperlukan adanya gagasan interkoneksi (Kuntowijoyo, 2004: 49). Interkoneksi menurut Amin Abdullah (2010: vii-viii) adalah usaha memahami kompleksitas fenomena kehidupan yang dihadapi dan dijalani manusia, setiap bangunan keilmuan apapun, baik keilmuan agama (termasuk agama Islam, dan agama-agama lain) keilmuan sosial, humaniora, maupun kealaman tidak dapat berdiri sendiri tanpa kerjasama, saling tegur sapa, saling membutuhkan, saling koreksi, dan saling berhubungan antardisiplin keilmuan. Pendekatan integratif-interkonektif adalah pendekatan yang berusaha saling menghargai; keilmuan umum dan agama sadar akan keterbatasan masing-masing dalam memecahkan persoalan manusia, hal ini akan melahirkan sebuah kerja sama setidaknya saling memahami pendekatan (approach) dan metode berpikir (process and procedure) antara kedua kelimuan tersebut (Abdullah, 2008: 242). 
Makalah ini berusaha membahas tentang praktik pendekatan integrasi-interkoneksi dalam kajian manajemen dan kebijakan pendidikan Islam yang difokuskan pada praktik manajemen pembelajaran pada kebijakan kurikulum 2013. Diketahui bahwa kebijakan kurikulum 2013 mengembangkan tiga ranah secara terintegrasi-interkoneksi berupa sikap (attitude), pengetahuan (knowledge), dan keterampilan (skill). Ketiga ranah tersebut adalah satu kesatuan utuh dan menjadi tagihan dalam proses pembelajaran yang relevan dengan konsep integrasi-interkoneksi. Pembehasan dimulai dari tela'ah bidang manajemen dan kebijakan pendidikan Islam, dan diakhiri dengan implementasi pendekatan integrasi-interkoneksi dalam manajemen dan kebijakan kurikulum 2013.

\section{Manajemen dan Kebijakan Pendidikan Islam}

1. Manajemen Pendidikan Islam

Setidaknya terdapat dua pengertian atau maksud dalam istilah "Manajemen Pendidikan Islam”. Pertama, Manajemen Pendidikan Islam dimaksudkan sebagai praktik manajemen di lembaga pendidikan Islam dan kedua, Manajemen Pendidikan Islam dimaksudkan sebagai sebuah konsep atau pemikiran tentang manajemen pendidikan dalam Islam.

Pada pengertian pertama Manajemen Pendidikan Islam sebagai ilmu terapan (applied science) yang diterapkan di lembaga-lembaga pendidikan Islam. Kata "Islam" disini berarti lembaga/organisasi pendidikan yang didirikan oleh umat Islam. Lembaga pendidikan Islam disini pada umumnya merujuk pada dua maksud yaitu; Pertama, lembaga pendidikan di bawah pengelolaan, pembinaan, koordinasi, atau tanggungjawab organisasi sosial keagamaan. Pada kasus ini, hampir setiap organisasi sosial keagamaan di Indonesia mengelola dan mengembangkan pendidikan sesuai dengan arah dan tujuan perjuangan organisasi diantaranya adalah Nahdlatul Ulama (NU), Muhammadiyah, Persis (Persatuan Islam), Mathlaul Anwar (MA), Persatuan Tarbiyah Islamiyah (Perti), Al Washliyah, dan lain-lain. Kedua lembaga pendidikan yang didirikan dan didedikasikan untuk pengembangan dan pelaksanaan pendidikanpengajaran yang berbasiskan ideologi dan semangat keislaman. Lembaga pendidikan semacam ini pada umumya dikelola dalam payung Yayasan Pendidikan Islam (YPI) yang berdiri sendiri dan tidak berafiliasi dengan lembaga sosial keagamaan mainstream seperti NU dan Muhammadiyah.

Manajemen pendidikan Islam dalam pengertian manajemen 
yang dipraktikkan di lembaga pendidikan Islam pada praktiknya adalah melaksanakan prinsip dan fungsi-fungsi manajemen di lembaga pendidikan Islam. Praktik manajemen yang berkembang dan biasa dijalankan di organisasi umum-sekuler dipinjam-diadopsi kemudian diterapkan di lembaga pendidikan Islam. Kata "Islam" dalam praktik manajemen semacam ini adalah lembaga/organisasi dan semangat (spirit), nilai keislaman yang menjiwai aktivitas organisasi.

Pada pengertian kedua, manajemen pendidikan Islam sebagai sebuah konsep atau pemikiran tentang manajemen pendidikan dalam Islam. Manajemen pendidikan Islam dalam pengertian ini dapat digolongkan dalam disiplin ilmu-ilmu murni (pure science). Persoalannya kemudian menjadi agak rumit ketika manajemen pendidikan Islam dalam rumpun ilmu-ilmu sosial-Humaniora "belum" dikenal dan belum mendapatkan dasar pijakannya. Masih diperlukan usaha dan pemikiran serius untuk meneguhkan Manajemen Pendidikan Islam ke dalam rumpun Ilmu-Ilmu Sosial-Humaniora yang berdiri sendiri.

Manajemen Pendidikan Islam sebagai sebuah Ilmu umumnya dimasukkan dalam rumpun Ilmu-Ilmu Sosial, dan diposisikan sebagai turunan dariilmuAdministrasi/Manajemen Publik(PublicAdministration) yang di dalamnya mencakup manajemen pendidikan, dan "Manajemen Pendidikan Islam”.

Praktik yang banyak terjadi dalam pembahasan konsep manajemen pendidikan Islam adalah upaya "Islamisasi" manajemen dalam Islam. Yaitu upaya justifikasi teori, prinsip, dan konsep manajemen pada umumnya ke dalam prinsip dan ajara Islam yang didasarkan pada sumber-sumber hukum dan pedoman hidup Islam (al-Qur'an, Hadits, Ijma, Qiyas, dll). Masih diperlukan jalan panjang, dan pemikiran sungguh-sungguh dalam upaya positioning manajemen pendidikan Islam dalam disiplin ilmu yang kokoh serta tidak sekedar labeling prinsip Islam dalam ilmu manajemen yang sudah mapan.

Manajemen pendidikan Islam pada dasarnya adalah seni dan ilmu mengelola sumberdaya pendidikan untuk mewujudkan suasana belajar dan proses pembelajaran agar peserta didik secara aktif mengembangkan potensidirinya untukmemiliki kekuatan spiritualkeagamaan, pengendalian diri, kepribadian, kecerdasan, akhlak mulia, serta keterampilan yang diperlukan dirinya, masyarakat, bangsa dan negara. 
Manajemen pendidikan Islam disebut sebagai seni karena praktik manajemen selalu bersinggungan, berhubungan dan bersinergi dengan orang-orang baik secara individu maupun kelompok dengan maksud bekerja bersama dan menggerakkannya sesuai dengan peran dan fungsinya masing-masing. Dalam hal ini maka manajemen pendidikan Islam merupakan seni menggerakkan orang-orang dalam rangka mencapai tujuan yang ditetapkan. Sedangkan manajemen pendidikan Islam sebagai ilmu menunjukkan sebagai upaya sistematis disiplin ilmu terapan (applied science) dalam memahami mengapa dan bagaimana manusia bekerja sama untuk mencapai tujuan, dan membuat sistem kerjasama tersebut bermanfaat bagi kemanusiaan. Upaya sistematis dalam manajemen pendidikan Islam diwujudkan dalam fungsi-fungsi manajemen: merencanakan (planning), mengorganisasikan (organizing), menggerakkan (actuating), dan mengontrol-mengevaluasi (controling/ evaluating).

Dengan kata lain manajemen pendidikan Islam adalah seluruh proses kegiatan bersama dalam lembaga pendidikan Islam dengan mendayagunakan semua sumberdaya yang ada, yang dikelola untuk mencapai tujuan pendidikan Islam secara efektif (do the right thingsmelakukan pekerjaan yang benar), efisien (do things right-melakukan pekerjaan dengan benar), dan produktif. Sumberdaya dalam konteks manajemen pendidikan Islam adalah berupa man (peserta didik, pendidik dan tenaga kependidikan), money (biaya/pendanaan), materials (bahan: kurikulum, informasi), methods (metode, teknik, strategi), machines (sarana dan prasarana), market (lulusan, pengguna lulusan/user), dan minutes (waktu). Sumberdaya pendidikan Islam (Islamic education resources) tersebut biasa di sebut $7 \mathrm{M}$ dan secara diagramatik dapat dilihat pada gambar 2.

Dengan demikian maka manajemen pendidikan Islam pada dasarnya merupakan penerapan dari prinsip manajemen pendidikan pada umumnya, sehingga manajemen pendidikan Islam mempunyai kekhasan dalam bidang tujuan, proses, dan orientasinya. Berdasarkan tujuannya, manajemen pendidikan Islam senantiasa bermuara pada tujuan pendidikan Islam, yaitu pengembangan fitrah dan aktualisasikan potensi peserta didik sebagai khalifah menuju kesempurnaan hidup atau insan kamil. Berdasar prosesnya, manajemen pendidikan Islam harus dilandasi dengan ruh dan semangat theologis-edukatif yang berkenaan 
dengan kemaslahatan manusia yang tidak semata-mata dilandasi prinsip efektivitas, efisiensi dan produktivitas, melainkan juga harus dilandasi dengan prinsip mendidik. Berdasar orientasinya, manajemen pendidikan Islam diorientasikan atau dipusatkan kepada peserta didik yang fitrah dan kaya potensi (student centre learning).

2. Kebijakan Pendidikan Islam

Para pengkaji kebijakan publik mempersoalkan dan membedakan pengertian "kebijakan" dan "kebijaksanaan" dalam studi kebijakan publik di Indonesia. Petanyaan yang sering diajukan adalah apakah kebijakan dan kebijaksanaan mempunyai arti yang sama atau berbeda?. Ali Imron (1995: 11-17) berpendapat bahwa kata "kebijaksanaan" merupakan terjemahan dalam bahasa inggris "policy" yang berarti mengurus masalah atau kepentingan umum, dan juga administrasi pemerintah. Sedangkan kebijakan adalah terjemahan dari "wisdom". Kata "policy" kemudian memunculkan beberapa istilah yaitu politic, policy, dan polici. Politic berarti seni dan ilmu pemerintahan (the art and science of government); policy berarti hal-hal mengenai kebijaksanaan pemerintah, dan polici yang berkenaan dengan pemerintahan. Sedangkan wisdom (kebijakan) adalah suatu ketentuan dari pimpinan yang berbeda dengan aturan yang ada, yang dikenakan kepada sesorang karena adanya alasan yang dapat diterima untuk tidak memberlakukan aturan yang berlaku. Dari pembedaan terminologi ini kemudian Imron mendefinisikan kebijaksanaan (policy) sebagai aturan-aturan yang semestinya dan harus diikuti tanpa pandang bulu, mengikat kepada siapa pun dengan kebijaksanaan tersebut. Sedangkan kebijakan (wisdom) adalah suatu ketentuan dari pimpinan yang berbeda dengan aturan yang ada, yang dikenakan kepada sesorang karena adanya alasan yang dapat diterima untuk tidak memberlakukan aturan yang berlaku.

Definisi lain terkait dengan kebijakan publik telah diungkapkan oleh para ahli. Riant Nugroho (2014:128) mengumpulkan dua puluh definisi mengenai kebijakan, dan masih banyak lagi definisi lain yang dirumuskan oleh para ahli sesuai dengan sudut pandang dan keilmuannya. Semua definisi tersebut tidak ada yang keliru, semua benar dan saling melengkapi. Di antara definisi kebijakan tersebut adalah definisi yang dikemuakn oleh Carl J. Friedrick (1963:79) sebagai berikut: 
"Public policy is a proposed course of action of a person, group, or government within a given environment providing obstacles and opportunities which the policy was proposed to utilize and overcome in an effort to reach a goal or realize an objective or purpose" (Kebijakan publik adalah serangkaian tindakan yang diusulkan seseorang, kelompok, atau pemerintah dalam suatu lingkungan tertentu dengan menunjukkan hambatan-hambatan dan kesempatan kesempatan terhadap pelaksanaan usulan kebijakan tersebut dalam rangka mencapai tujuan tertentu).

James E. Anderson (1979: 3); "Public policies are those policies developed by governmental bodies and officials" (Kebijakan publik adalah kebijakan-kebijakan yang dikembangkan oleh badan-badan dan pejabat-pejabat pemerintah), dan Syafaruddin (2008: 77) mengartikan kebijakan publik sebagai hasil pengambilan keputusan oleh manajemen puncak baik berupa tujuan, prinsip maupun aturan yang berkaitan dengan hal-hal strategis untuk megarahkan pada manager dan personel dalam menentukan masa depan organisasi yang berimplikasi bagi kehidupan masyarakat.

James E Anderson mendefinisikan kebijakan publik sebagai " $a$ relative stable, purposive course of action followed by an actor or set of actors in dealing with a problem or matter of concern" (Serangkaian tindakan yang mempunyai tujuan tertentu yang diikuti dan dilaksanakan oleh seorang pelaku atau sekelompok pelaku guna memecahkan suatu masalah tertentu). Thomas R Dye "is whatever government choose to do or not to do. Public policy is what government do, why they do it, and what defference it makes". David Easton "the impact og government activity". Kraft dan Furlong (2004: 4) "a course of government action (or in action) take in respose to social problems. Social problems are conditions the public widely perceives to be unacceptable and therefore requiring intervention.

Dari berbagai definisi tersebut kemudian Riant Nugroho (2014: 129) memberikan pengertian kebijakan publik sebagai "any of state or government (as the holder of the authority) decision to manage public life (as the sphere) in order to reach the mission of the nation", yang secara sederhana dimaknai sebagai “...setiap keputusan yang dibuat oleh negera, sebagai strategi untuk merealisasikan tujuan dari Negara. Kebijakan publik adalah strategi untuk mengatur masyarakat pada masa awal, memasuki 
masyarakat pada masa transisi, untuk menuju masyarakat yang dicitacitakan”.

Beberapa pengertian kebijakan, dan kebijakan publik tersebut, jika dikaitkan dengan kebijakan pendidikan Islam (Islamic education policy) secara sederhana dapat diartikan sebagai seperangkat aturan atau keputusan yang dibuat dan dirumuskan melalui proses pengambilan keputusan oleh pejabat publik (pemerintah) mengenai pendidikan Islam dalam rangka mencapai tujuan tertentu (Islamic education policy is a set of rules or the decision made through decision-making process and formulated by the public officer (government) about the islamic education).

\section{Kajian Manajemen dan Kebijakan Pendidikan Islam}

Manajemen pendidikan Islam sebagai sebuah sistem mempunyai cakupan yang sangat luas. Sistem dalam pengertian ini adalah kumpulan dari elemen-elemen yang menjadi satu kesatuan utuh dan saling mempengaruhi untuk mencapai tujuan atau sasaran yang dikehendaki (Winardi, 2007). Sebuah sistem selalu dijumpai komponen input, process, output, dan outcome. Dalam kontek manajemen pendidikan Islam sitem manajemen pendidikan Islam dapat digambarkan sebagai berikut:

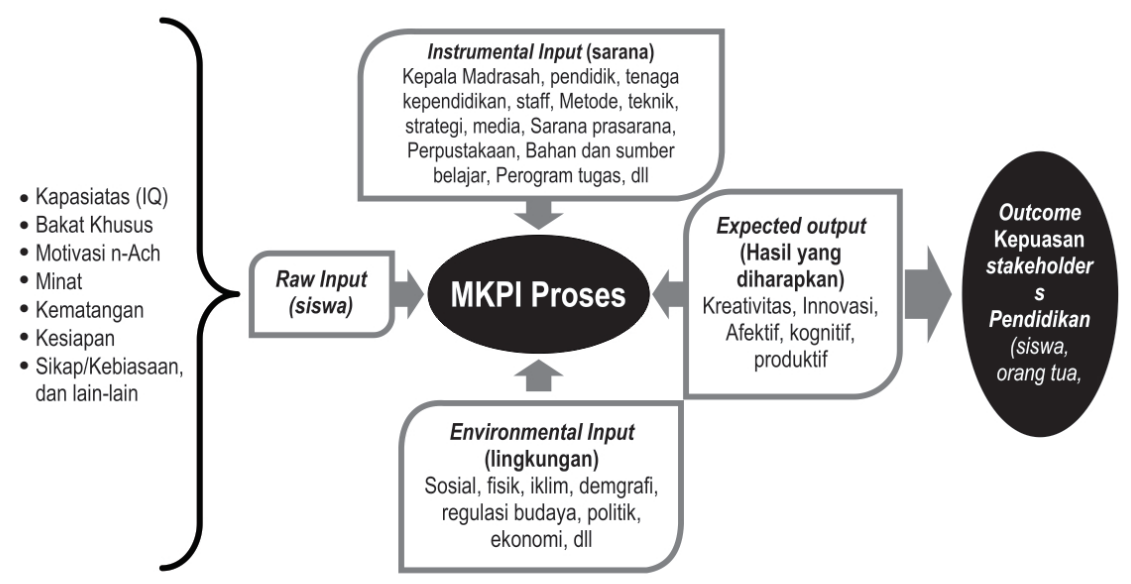

Gambar 1

Manajemen Pendidikan Islam dalam Kerangka Sistem 
Gambar tersebut menunjukkan bahwa secara sistematik komponen input (raw input, instrumental input, environmental input,) dalam manajemen pendidikan Islam sangat mempengaruhi proses dan performance output, dan akan sangat berdampak pada outcome-nya berupa kepuasan.

The expected output (hasil yang diharapkan) merupakan hasil yang diinginkan dari proses manajemen pendidikan Islam yang efektif, efisien dan produktif. Hasil yang diharapkan ini bisa berupa perilaku peserta didik sebagai akibat dari proses pembelajaran (pengelolaan pendidikan) yang baik meliputi pengetahuan (perilaku kognitif), keterampilan (perilaku psikomotorik), dan sikap (perilaku afektif). Raw input (karakteristik peserta didik), menunjukkan kepada faktor-faktor yang terdapat dalam diri individu seperti kapasiatas (IQ), bakat khusus, motivasi n-Ach, minat, kematangan, kesiapan, sikap/kebiasaan, dan lain-lain. Instrumental input (sarana), menunjukkan kepada kualifikasi serta kelengkapan sarana dan prasarana yang diperlukan untuk dapat berlangsungnya sistem pendidikan. Environmental input (lingkungan), menunjukkan situasi dan keadaan fisik (sekolah, letak sekolah, iklim, budaya, kondisi sosial, politik, ekonomi). Kesemua hal tersebut merupakan satu kesatuan sistem dalam rangka mencapai tujuan pendidikan Islam melalui pengelolaan (manajemen) pendidikan Islam yang efektif, efisien, dan produktif.

Hasil yang diharapkan dari manajemen pendidikan Islam adalah produktivitas lembaga. Produktivitas lembaga pendidikan dapat dilihat dari efektivitas dan efisiensi. Efektivitas adalah kesepadanan antara masukan dan keluaran yang merata dan bermutu tinggi. Sedangkan efisiensi adalah merujuk pada motivasi belajar yang tinggi, semangat belajar, kepercayaan berbagai pihak dan pembayaran, waktu dan tenaga yang sekecil mengkin dengan hasil yang sebesar-besarnya.

\section{Ketersinggungan (Intersection) Manajemen Pendidikan Islam dengan Ilmu-Ilmu Lain}

Sesuatu dapat dikatakan sebagai disiplin ilmu yang berdiri sendiri mensyaratkan obyek kajian yang jelas. Obyek kajian tersebut terdiri dari dua hal yaitu obyek material dan obyek formal. Obyek kajian inilah yang membedakan antara ilmu satu dengan yang lainnya.

Obyek material adalah sasaran material suatu penyelidikan, pemikiran atau penelitian ilmu, atau dalam pengertian lain, obyek material 
adalah bahan yang menjadi tinjauan penelitian atau pembentukan pengetahuan. Obyek material juga berarti hal yang diselidiki, dipandang atau disorot oleh suatu disiplin ilmu. Obyek material kajian manajemen pendidikan adalah sebagaimana obyek material ilmu lain yaitu manusia. Obyek formal "manusia" dalam kontek ini adalah dalam sebuah kerjasama organisasi/lembaga dan sistem pendidikan.

Obyek formal adalah sesuatu yang membedakan bidang ilmu satu dengan bidang lain. Obyek formal adalah sudut pandang yang ditujukan pada bahan dari penelitian atau pembentukan pengetahuan itu, atau sudut pandang darimana obyek material itu disorot. Sebuah ilmu pengetahuan dengan mudah diketahui dengan mengetahui obyek formalnya.

Obyek formal manajemen pendidikan Islam adalah keteraturan, pengaturan atau keserasian dalam pelaksanaan pendidikan di lembaga pendidikan Islam. Keteraturan dalam hal ini adalah hubungan antara satu pihak sebagai pengatur dengan pihak lain sebagai yang diatur, baik dalam internal kerjasama maupun eksternal, individu maupun kelompok dalam bidang pendidikan.

Penjelasan tersebut menunjukkan bahwa manajemen pendidikan Islam mempunyai bahasan yang jelas terkait dengan pengaturan, keserasian dalam organisasi. Manajemen pendidikan Islam merupakan disiplin ilmu terapan (applied science) dari kelompok ilmu-ilmu sosial (humaniora), karena kemanfaatannya hanya ada apabila prinsip-prinsipnya diterapkan untuk meningkatkan kebaikan hidup manusia. Keberadaannya sebagai disiplin ilmu terapan (applied science), "manajemen pendidikan Islam" dan juga "kebijakan pendidikan Islam" dalam parksisnya akan selalu bersinggungan dengan disiplin ilmu lain. Sebab keduannya merupakan turunan dan pecahan dari ilmu sosial-humaniora.

\section{Integrasi-Interkoneksi dalam Manajemen Kebijakan Pendidikan; Kasus Manajemen dan Kebijakan Kurikulum 2013}

Pada bagian ini diulas bagaimana implementasi integrasi pendekatan integrasi-interkoneksi dalam manajemen dan kebijakan pendidikan Islam yang difokuskan pada kasus pemberlakuan kebijakan dan praktik Kurikulum 2013. Diketahui bahwa tahun 2013 telah dikeluarka kebijakan kurikulum 2013 yang sekaligus melengkapi proses evolusi dan dinamika perkembangan kurikulum pendidikan di Indonesia. Mulai dari masa pra-kemerdekaan dengan bentuk yang sangat sederhana, dan 
masa kemerdekaan yang terus menerus disempurnakan yaitu pada tahun 1947, 1952, 1964, 1968, 1975, 1984, 1994, 2004, 2006, dan tahun 2013. Dalam konteks ini kurikulum sebagai produk kebijakan bersifat dinamis, kontekstual, dan relatif. Dinamis sebab terus berkembang dan disesuaikan dengan perkembangan zaman serta terbuka terhadap kritik. Kontekstual karena sangat dibutuhkan dan didasarkan pada konteks zamannya, dan relatif sebab kebijakan kurikulum yang dihasilkan dipandang bagus atau sempurna pada zamannya, dan akan menjadi tidak relevan pada zaman-zaman berikutnya. Oleh karenanya prinsip dasar dalam kebijakan kurikulum adalah change and continuity yaitu perubahan yang dilakukan secara terus menerus (Machalli, 2014: 71-94).

Terdapat tiga hal dalam pembahasan kurikulum dan pengembangannya yaitu pertama kurikulum sebagai rencana (as a plan) yang menjadi pedoman (guideline) dalam mencapai tujuan yang akan dicapai. Kedua, kurikulum sebagai materi atau isi (curriculum as a content) yang akan disampaikan kepada peserta didik, dan ketiga, dengan cara apa dan bagaimana kurikulum disampaikan. Ketiga hal tersebut adalah satu kesatuan dan bersinergi dalam rangka mencapai tujuan pendidikan yang diinginkan. Oleh karena itu, pengembangan kurikulum dapat difahami sebagai sebuah proses penyusunan rencana tentang isi atau materi pelajaran yang harus dipelajari dan bagaimana cara mempelajarinya. Dalam hal ini pengembangan kurikulum adalah sebuah proses yang terus menerus (continue), dinamis (dynamic), dan kontekstual (contextual).

Kebijakan perubahan Kurikulum 2013 merupakan sebuah ikbtiar dan wujud dari prinsip dasar kurikulum change and continuity, yaitu hasil dari kajian, evaluasi, kritik, respon, prediksi, dan berbagai tantangan yang dihadapi. Kurikulum 2013 diyakini sebagai kebijakan strategis dalam menyiapkan dan menghadapi tantangan dan tuntutan masyarakat Indonesia masa depan.

\section{Manajemen dan Kebijakan Pembelajaran Kurikulum 2013}

Perubahan Kurikulum 2013 merupakan wujud pengembangan dan penyempurnaan dari kurikulum sebelumnya kurikulum KTSP tahun 2006 yang dalam kajian implementasinya dijumpai beberapa masalah. Kurikulum 2013 menitikberatkan pada penyempurnaan pola pikir, penguatan tata kelola kurikulum, pendalaman dan perluasan materi, penguatan proses pembelajaran, dan penyesuaian beban belajar agar 
dapat menjamin kesesuaian antara apa yang diinginkan dengan apa yang dihasilkan. Atas dasar tersebut, penyempurnaan dan implementasi Kurikulum 2013 diyakini sebagai langkah strategis dalam menyiapkan dan menghadapi tantangan globalisasi dan tuntutan masyarakat Indonesia masa depan. Dalam kerangka inilah kurikulum 2013 memerankan fungsi penyesuaian (the adjusted or adaptive function) yaitu kurikulum yang mampu mengarahkan peserta didiknya mampu menyesuaikan dirinya dengan lingkungan, baik lingkungan fisik maupun lingkungan sosial yang terus berubah. Kurikulum 2013 mengintegrasikan tiga ranah kompetensi yaitu sikap, pengetahuan dan ketrampilan yang dalam implementasinya terangkum dalam KI-1 (sikap spiritual), KI-2 (sikap sosial), KI-3 (pengetahuan), dan KI-4 (ketrampilan). Keempat kompetensi tersebut diyakini dapat menghasilkan peserta didik yang Produktif, Kreatif, Inovatif, Afektif melalui penguatan intengrasi Sikap, Pengetahuan, dan Keterampilan.

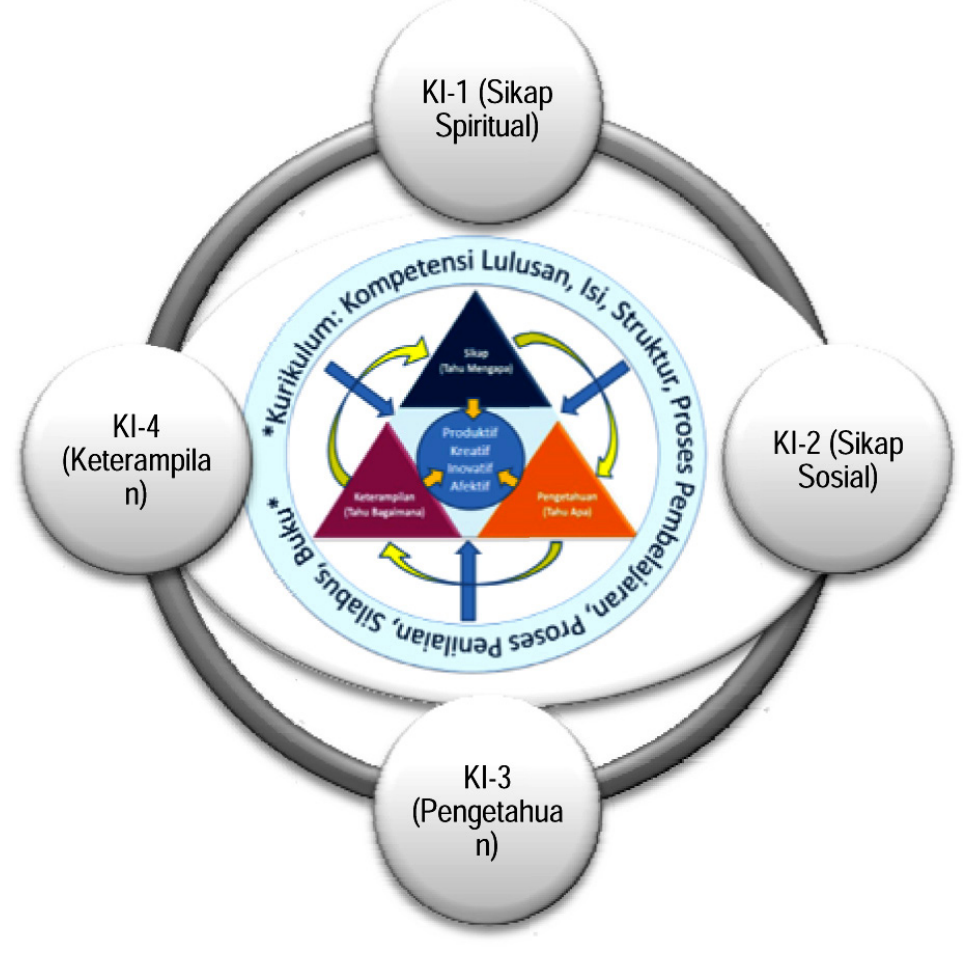

Gambar 2

Integrasi Sikap, Pengetahuan dan Ketrampilan dalam Kurikulum 2013 
Ke-empat aspek tersebut (kompetensi Inti) merupakan satu kesatuan (integrasi) tagihan yang harus terpenuhi, tercapai dan terimplementasikan dalam proses belajar mengajar. Pada kurikulum 2013, pembelajaran pada setiap mata pelajaran tidak hanya fokus pada pengetahuan saja (KI-3) sebagaimana yang sering terjadi pada praktik pembelajaran sebelumnya akan tetapi setiap guru, setiap mata pelajaran bertanggungjawab atas penyampaian, dan ketercapaian keempat aspek Kompetensi Inti (KI) tersebut. Dari sini maka seorang pendidik dituntut tidak hanya menguasai satu bidang ilmu yang hanya menjadi tanggugjawabnya saja, akan tetapi mengetahui, memahami, mendialogkan dan meng- "integrasi-interkoneksikan" disiplin ilmu lain dengan mata pelajaran yang diajarkan. Hal ini dilakukan dalam rangka ketercapaian tagihan kompetensi yang harus dicapai oleh peserta didik. Lebih-lebih dalam pendekatan pembelajaran yang harus dilakukan dalam kurikulum 2013 adalah menggunakan pendekatan scientific yaitu sebuah pendekatan yang memungkinkan peserta didik secara aktif-partsipatif mengembangkan nalar, merangkai, mengkaitkan satu hal dengan hal yang lain melalui lima tahap yaitu mengamati (observing), menanya (questioning), mengeksplorasi (eksploring), mengasosiasi (associating), dan mengkomunikasikan (communicating).

Dalam praktik pembelajaran semacam ini, sebagaimana tuntutan Kurikulum 2013 dikotomi ilmu pengetahuan yang mempertentangkan antara ilmu agama versus ilmu umum, sekuler versus agama, akhirat versus duniawi, hati/keyakinan versus nalar/rasional, dan sebagainya menjadi tipis untuk tidak mengatakan hilang dan terus akan berinteraksi, berintegrasi-interkoneksi. Mata pelajaran agama (pendidikan Agama) dituntut harus mampu didialogkan, diingintegrasi-interkoneksikan dengan berbagai disiplin lain (pengetahuan umum) dengan kajian-kajian "ilmiah-scietifik". Sebaliknya mata pelajaran umum juga harus mampu didialogkan, diingintegrasi-interkoneksikan dengan ilmu-ilmu agama. Dalam proses integrasi-interkoneksi semacam ini pendidik sebagai kunci proses pembelajaran (learning process) dituntut megembangkan ilmu, wawasan, bacaan, dan kompetensinya pedagogik dan professional secara interdisipliner dalam rangka ketercapaian tagihan kompetensi inti yang harus dicapai. Guru dituntut menguasai bidang ilmu yang menjadi tugas dan tanggungjawab mengajarnya dan sekaligus memperkaya wawasannya, mendialogkannya dengan ilmu-ilmu pendukung lainnya. Sebab tuntutan 
pembelajaran dalam kurikulum 2013 adalah penguasaan empat ranah kompetensi sebagaimana yang telah disebutkan sebelumnya.

Kompetensi Inti 1 (KI-1: sikap spiritual), dan KI-2 (sikap sosial), dalam praktik pembelajarannya tidak secara langsung diajarkan, akan tetapi langsung dipraktikkan. Proses pembelaaran dimulai dari KI-3 (pengetahuan), dan KI-4 (keterampilan). Dalam penjelasan implementasi kurikulum 2013 dijelaskan bahwa Kurikulum 2013 mengembangkan dua modus proses pembelajaran yaitu proses pembelajaran langsung dan proses pembelajaran tidak langsung (Permendikbud Nomor 81A Tahun 2013). Proses pembelajaran langsung adalah proses pendidikan di mana peserta didik mengembangkan pengetahuan, kemampuan berpikir dan keterampilan psikomotorik melalui interaksi langsung dengan sumber belajar yang dirancang dalam silabus dan RPP (Rencana Pelaksanaan Pembelajaran) berupa kegiatan-kegiatan pembelajaran. Dalam pembelajaran langsung tersebut peserta didik melakukan kegiatan belajar mengamati, menanya, mengumpulkan informasi, mengasosiasi atau menganalisis, dan mengkomunikasikan apa yang sudah ditemukannya dalam kegiatan analisis. Proses pembelajaran langsung menghasilkan pengetahuan dan keterampilan langsung atau yang disebut dengan instructional effect.

Pembelajaran tidak langsung adalah proses pendidikan yang terjadi selama proses pembelajaran langsung tetapi tidak dirancang dalam kegiatan khusus. Pembelajaran tidak langsung berkenaan dengan pengembangan nilai dan sikap. Berbeda dengan pengetahuan tentang nilai dan sikap yang dilakukan dalam proses pembelajaran langsung oleh mata pelajaran tertentu, pengembangan sikap sebagai proses pengembangan moral dan perilaku dilakukan oleh seluruh mata pelajaran dan dalam setiap kegiatan yang terjadi di kelas, sekolah, dan masyarakat. Oleh karena itu, dalam proses pembelajaran Kurikulum 2013, semua kegiatan yang terjadi selama belajar di sekolah dan di luar dalam kegiatan kokurikuler dan ekstrakurikuler terjadi proses pembelajaran untuk mengembangkan moral dan perilaku yang terkait dengan sikap, baik sikap spiritual (KI-1) maupun sikap sosial (KI-2).

Baik pembelajaran langsung maupun pembelajaran tidak langsung terjadi secara terintegrasi dan tidak terpisah. Pembelajaran langsung 
berkenaan dengan pembelajaranyang menyangkutKDyang dikembangkan dari KI-3 dan KI-4. Keduanya, dikembangkan secara bersamaan dalam suatu proses pembelajaran dan menjadi wahana untuk mengembangkan KD pada KI-1 dan KI-2. Pembelajaran tidak langsung berkenaan dengan pembelajaran yang menyangkut KD yang dikembangkan dari KI-1 dan KI-2.Pembelajaran semacam ini merupakan wujud integrasi-interkoneksi yang dikelola menjadi satu sistem manajemen pembelajaran.

\section{Contoh Implementasi Integrasi-Interkoneksi Manajemen Pembelajaran dalam Kurikulum 2013}

Integrasi-interkoneksi manajemen pembelajaran dalam kurikulum 2013 dalam dicontohkan sebagai berikut. Dalam pembelajaran Pendidikan Agama Islam (PAI) misalnya, meteri Thaharah (bersuci) membahas mengenai air. Air dalam bab thaharah ini umumnya terbagi menjadi Air Mutlak, (air suci dan mensucikan), Air Musta'mal (air yang telah terpakai), Air Mutanajjis (air yang terkena najis). Manajemen pembelajaran mengenai air ini seorang pendidik dituntut tidak haya menyampaikan secara normatif-literer tentang air sebagaimana dalam ilmu-ilmu figh saja, dengan eksplorasi al-qur'an dan hadits. Akan tetapi harus mampu mendialogkan, dan menghubungkannya dengan faktafakta ilmiah tentang air, dampak, dan fungsi air bagi kehidupan. Oleh karena itu, pendidik harus mempunyai wawasan, bacaan, dan literatur yang cukup untuk mampu memberikan berbagai informasi mengenai thaharah kepada peserta didik. Sebagai contoh adalah air dalam perspektif kajian ilmiah sebagaimana riset yang dilakukan oleh peneliti Jepang Masaru Emoto yang dibukukan dengan judul The True Power of Water, Healing and Discovering Ourselves (Emoto, 2006). Dalam risetnya, Emoto menemukan berbagai bentuk kristal dari berbagai macam air. Kristal-kristal yang terbentuk dari air tersebut akan berbentuk indah dan sempurna jika diberikan respon positif, seperti kata "terima kasih", "bagus sekali", "kebahagiaan", "cinta dan terima kasih". Sebaliknya jika diberikan respon negatif seperti, "kamu bohoh", "tidak berguna", "penderitan”, maka air sulit sekali untuk membentuk kristal, bahkan bentuk yang didapatkan jauh dari bentuk kristal.

Perspektif yang lain pendidikan juga seharusnya mampu mengaitkan materi thaharab; bersuci; air dengan kajian lain (misalnya ekologi, geologi, hidro-kimia, biologi, kesehatan d1l); jumlah air yang ada di bumi tidak 
bertambah dan berkurang hanya pindah dari satu tempat ke tempat lain, bumi terdiri dari 70 persen air (lautan), dan 30 persen daratan, begitu juga keadaan manusia 70 persen adalah air karenanya air juga akan mempengaruhi mood kita. Bila kita diberi respon positif, air yang ada dalam tubuh kita akan menangkap energi tersebut, sehingga kita akan merasakan hal yang lebih baik, terjadinya kerusakan lingkungan, abrasi, dan krisis air disebabkan oleh ulah manusia yang tidak bijak dalam penggunaan air.

Riset yang dilakukan oleh seorang psikiater dan sekaligus neurology berkebangsaan Austria bernama Leopold Werner von Ehrenfels dalam hal wudhu (bersuci dengan menggunakan air) menjelaskan tentang hal yang menakjubkan dari wudhu ini. Ia mengemukakan bahwa pusatpusat syaraf yang paling peka, yaitu sebelah dahi, tangan, dan kaki. Pusat-pusat syaraf tersebut sangat sensitif terhadap air segar. Dari sini ia menghubungkan hikmah wudhu yang membasuh pusat-pusat syaraf tersebut. Ia bahkan merekomendasikan agar wudhu (bersuci) bukan hanya milik dan kebiasaan umat Islam, tetapi untuk umat manusia secara keseluruhan. Dengan senantiasa membasuh air segar pada pusatpusat syaraf tersebut, maka berarti orang akan memelihara kesehatan dan keselarasan pusat sarafnya. Lain halnya dengan Oan Hasanuddin dalam perspektif kesehatan menunjukkan bahwa anggota badan yang dibasuh air wudhu memiliki titik akupresure dan akupunktur yang sangat bermanfaat bagi kesehatan seseorang. Titik-titik tersebut merupakan bagian titik pijat dan akupunktur untuk mengobati berbagai macam penyakit (qultummedia.com).

Contoh manajemen pembelajaran semacam ini dapat dilakukan di semua mata pelajaran, baik agama maupun umum seperti mata pelajaran biologi tentang proses penciptaan manusia. Proses pembelajaran dapat dimulai dengan mengamati (observing) video yang menunjukkan faktafakta ilmiah, kemudian mengintegrasikannya dengan sains qur'an dan hadits. Lagi-lagi kemampuan semacam ini harus didukung dengan wawasan, bacaan, pengalaman, dan literatur memadai bagi guru yang melekat pada kompetensi pedagogik dan profesionalnya.

Diujung proses pembelajaran, pendidik secara bersama-sama menyimpulkan tentang sikap/nilai terhadap thaharab/bersuci; sikap sosial (KI-2), dan sikap spiritual (KI-1) bahwa kita harus bijak menggunakan air, tidak boleh berlebih-lebihan, menjaga lingkungan, kebersihan, dan 
harus bersyukur atas karunia Allah terhadap air yang diberikan. Sikap Sosial (KI-2) dari proses penciptaan manusia dalam mata pelajaran biologi dapat berupa persaudaraan karena semua manusia berasal dari rahim yang satu dan lain-lain. Sedangkan Sikap Spiritual (KI-1) berupa rasa syukur atas kelebihan manusia dibading dengan mahluk lain. Sekali lagi, penyampaian sikap sosial berupa "menghayati dan mengamalkan perilaku jujur, disiplin, tanggungjawab, peduli, (gotong royong, kerjasama, toleran), santun, responsive dan pro-aktif,...." dan Sikap Spiritual berupa "menghayati dan menjalankan ajaran agama yang dianutnya" ini melalui pembelajaran tidak langsung yang diperlihatkan dalam ujuk kerja nyata bukan unjuk kerja semu melalui perilaku peserta didik. Dengan demikian integrasi-interkoneksi manajemen pembelajaran semacam ini akan menghasilkan peserta didik yang "berilmu amaliyah, beramal ilmiah, dan berakblakul karimab".

\section{Simpulan}

Upaya implementasi konsep integrasi-interkoneksi harus terus dilakukan untuk mempersempit ruang dualisme atau dikotomi ilmu yang memisahkan antara pendidikan umum dari pendidikan agama yang kemudian berdampak pada pemisahan dan pemilahan kesadaran keagamaan dan ilmu pengetauan umum. Lebih lanjut, kesadaran dikotomistik ini menjadi penyebab sebagaimana analisis pemikir muslim kemunduruan penguasaan ilmu pengetahuan di dunia Islam. Tidak itu saja, dikotomi menyebabkan menjauhnya agama dengan realitas kehidupan umat.

Implementasi pendekatan integrasi-interkoneksi dilakukan tidak hanya pada ranah pemikiran saja, akan tetapi pada praktik-aplikatifnya dalam proses pembelajaran. Manajemen pembelajaran dalam kebijakan kurikulum 2013 adalah contoh praktik integrasi-interkoneksi yang baik, dimana Kurikulum 2013 mengintegrasikan tiga ranah kompetensi yaitu sikap (attitude), pengetahuan (knowledge), dan ketrampilan (skill) yang di implementasikan dalam KI-1 (sikap spiritual), KI-2 (sikap sosial), KI-3 (pengetahuan), dan KI-4 (ketrampilan). Keempat aspek ini (kompetensi Inti) merupakan satu kesatuan (integrasi) tagihan yang harus terpenuhi, tercapai dan terimplementasikan dalam proses belajar mengajar.

Praktik pembelajaran dengan pendekatan scientific-observing, questioning, exploring, associating, dan communicating-sebagaimana 


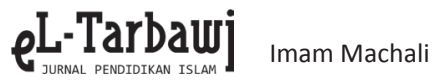

tuntutan Kurikulum 2013 diyakini akan mempersempit ruang dikotomi dan mengintegrasi-interkoneksikan berbagai mata pelajaran. Oleh karena itu, pendidik sebagai kunci proses pembelajaran (learning process) dituntut megembangkan ilmu, wawasan, bacaan, dan kompetensinya secara interdisipliner dalam rangka ketercapaian tagihan kompetensi inti yang harus dicapai. 


\section{Daftar Pustaka}

Abdullah, Amin. (dkk), Menyatukan Kembali Ilmu-Ilmu Agama dan Umum; Upaya Mempertemukan Epistemologi Islam dan Umum, Yogyakarta: Suka Press, 2003.

Abdullah, Amin. "Desain Pengembangan Akademik IAIN menuju UIN Sunan Kalijaga: dari penekatan Dikotomis-Atomistis ke arah integratif-interdisiplinary" dalam Zainal Abidin Bagir, Integrasi Ilmu dan Agama, Yogyakarta: Pustaka Pelajar, 2008

Abdullah, Amin. Islamic Studies di Perguruan Tinggi:Pendekatan IntegratifInterkonektif,(Yogyakarta: Pustaka Pelajar, 2010

Anderson, James E. Public Policy Making, New York: Holt, Rinehart and Winston, 1979

Bastaman, Hanna Djumhana. Islamisasi Sains dengan Psikologi sebagai Ilustrasi, Jurnal Ulumul Qur'an Vol. II.1991/1411: 10-17.

Daud, Wan Mohd Nor Wan. Filsafat dan Praktik Pendidikan Islam Syed M. Naquib Al-Attas (trj) The Education Philosophy and Practice of Syed M. Naquib Al-Attas. Bandung: Mizan, 2003

Daud, Wan Mohd Nor Wan. The Educational Philosophy and Practice of Syed M. Naquib Al-Attas, Malaysia: ISTAC, 1998

Direktorat Jenderal Pendidikan Islam, Direktorat Pendidikan Agama Islam, Pedoman Umum Implementasi Kurikulum 2013, Jakarta; Kementerian Agama RI, 2013

Dunn, William N. Public Policy Analisys: An Introduction, terj Samudra Wibawa, dkk. Yogyakarta: Gajah Mada University Press, 1998

Dyers, J.H. et al. Innovators DNA: Mastering the Five Skills of Disruptive Innovators, Harvard Business Review, 2011.

Emoto, Masaru. The True Power of Water, Hikmah Air dalam Olah Jiwa, Bandung: MQPublishing, 2006

Friedrick, Carl J. Man and His Government, New York: Mc Graw Hill, 1963

Hidayat, Sholeh. Pengembangan Kurikulum Baru, Bandung: Rosda, 2013 
Hitti, Philip K. History of The Arab, London: Macmillan Press Ltd, 1974 http://qultummedia.com/44-artikel/ibadah/651-bukti-ilmiah-mukjizatwudhu diakses pada [2 Oktober 2014]

Imron, Ali. Kebijaksanaan Pendidikan di Indonesia; Proses, Produk, dan Masa Depannya, Jakarta: Bumi Aksara, 1995

Kartanegara, Mulyadi. Integrasi Ilmu: Sebuah Rekontruksi Holistik, Bandung: Arasyi Mizan, 2005

Kraft, Michael E. and Scoot R. Furlong, Public Policy: Politics, Analysis, and Alternatives, Washington: Congress Quarterly Press, 2004

Kuntowijoyo, Islam sebagai Ilmu: Epistemologi, Metodologi dan Etika, Yogyakarta: Teraju, 2004

Machali, Imam. \& Ara Hidayat, Pengelolaan Pendidikan; Konsep, Prinsip dan Aplikasi dalam Mengelola sekolah dan Madrasah, Yogyakarta; Kaukaba, 2012

Machali, Imam. Kebijakan Kebijakan Perubahan Kurikulum 2013 dalam Menyongsong Indonesia Emas Tahun 2045. Jurnal Pendidikan Islam, 3 (1) Juni 2014/1435: 71-94

Nugroho, Riant. Public Policy, Teori, Manajemen, Dinamika, Analisis, Konvergensi, dan Kimia Kebijakan, Jakarta: PT Elex Media Komputindo, 2014

Oliva, Peter F. Developing the Curriculum, New York: HarperCollins Publisher, 1992

Peraturan Menteri Pendidikan dan Kebudayaan Republik Indonesia 81A tentang Implementasi Kurikulum, 2013

Raharjo, Rahmat. Pengembangan E' Inovasi Kurikulum, Yogyakarta: Baituna Publishing, 2012

Rahman, Fazlur. Islam and Modernity: Transformation of an Intelectual Tradition Chicago: The Chicago University Press, 1984

Sanjaya, Wina. Kurikulum dan Pembelajara, Jakarta: Kencana, 2008

Syafaruddin, Efektifitas Kebijakan; Konsep, Strategi dan Aplikasi Kebijakan Menuju Organisasi Sekolah Efektif, Jakarta: Rineka Ciota, 2008 
Wahyono, Andi. Kebijakan Pendidikan Islam; Hibridasi Lembaga Pendidikan Tinggi. Jurnal Pendidikan Islam, 3 (1) Juni 2014/1435: $115-134$

Winardi, J. Pemikiran Sistemik dalam Bidang Organisasi dan Manajemen, Jakarta: Rajawali, 2007 